\author{
Krzysztof Magnucki \\ Eukasiewicz - Rail Vehicles Institute "TABOR" \\ Dennis Alsdorf \\ Havel Metal Foam GmbH \\ Jerzy Lewiński \\ Michat Kowalski \\ Łukasiewicz - Rail Vehicles Institute "TABOR" \\ Alexander Richter \\ Havel Metal Foam GmbH \\ Andrzej Zbierski \\ Eukasiewicz - Rail Vehicles Institute "TABOR"
}

\title{
Analytical, FEM-numerical and experimental studies of bending of a sandwich plate-strip with metal foam core
}

\begin{abstract}
The subject of the study is a sandwich plate-strip subjected to a four-point load. An analytical model of the strip was developed, taking into account the classical zig-zag theory, namely the broken line hypothesis. Three parts of the plate-strip are distinguished: two of them are the edge parts, where bending and the shear effect is considered, the third one is the middle part subjected to pure bending. The total maximum deflection of the plate-strip and the maximum deflection of the selected middle part of the plate-strip are calculated. The FEM-numerical study is carried out similarly to the analytical approach. The experimental study was carried out on the test stand in the Institute of Rail Vehicles TABOR. The analytical, numerical and experimental results are compared each with other. The sandwich panels can be used as parts of the floor or rail vehicle paneling.
\end{abstract}

\section{Introduction}

The basis of analytical modelling of sandwich structures was initiated in the middle of the $20^{\text {th }}$ century. Vinson [16] presented a review of the works written in the $20^{\text {th }}$ century, dealing with the problems of structural mechanics applied to the sandwich structures. Reddy [14] provided an extensive monograph devoted to laminated composite plates and shells. The author described the methods of modeling and analysis of these structures, inclusive of various theories used for this purpose. Magnucki and Szyc [8] presented a co-author monograph on the strength and stability problems of sandwich beams and plates with aluminium foam cores. Kozak [5] described the use of the steel sandwich panels in ship structures.

Sayyad and Ghugal [15] submitted a critical review of the literature devoted to laminated composite and sandwich structures, published mainly in the $21^{\text {st }}$ century. The work quotes various theories and hypotheses applicable in this field and highlights a possible scope for the future research. Banhart [1] considered the problems of manufacturing metal foams and other porous metallic structures. The author quotes various innovatory production methods and the ways for characterizing the properties of cellular metals. The paper also presents the fields of application of these materials in various industrial branches. Icardi [2] developed a model designed for analysis of laminated and sandwich beams. The displacements are so formulated as to satisfy the continuity conditions of the transverse shear, transverse normal stress and stress gradient.

The zig-zag hypothesis improves accuracy of the approach that is compared with other 3-D elasticity solutions and with various models available in the literature. Jasion and Magnucki [3] dealt with the sandwich beams subjected to four-point bending. The principle of stationary total potential energy enabled to derive the formulae determining the critical stresses in the faces of the beam, related to upper face wrinkling. The results obtained based on the analytical model and FEM analysis are shown for several sandwich beams with various thicknesses and core properties. Jasion et al. [4] investigated the global and local buckling of the face sheets of sandwich beams and sandwich circular plates. A mathematical model of the displacements, with consideration of the shear effect, is developed.

The analytical solutions are compared to the results obtained with the use of Finite Element Method and with experimental methods. Magnucka-Blandzi and Magnucki [6] analyzed a simply supported sandwich beam with a metal foam core. Nonlinear hypothesis of deformation of the beam plane cross 
section and the theorem of minimum total potential energy enabled to derive the differential equations of equilibrium. Their solution allowed to determine optimal dimensionless parameters of the beam.

Magnucka-Blandzi [7] considered a simply supported rectangular sandwich plate compressed in plane. Assumption of the field of displacements and geometric relationships allowed to derive a system of differential equations and, in consequence, to determine the critical loads for a family of the sandwich plates. Magnucki et al. [9], [10] and [11] analyzed the structures provided with an aluminum foam core. The studies have been devoted to a five-layer sandwich beam under axial compression or bending and to sandwich circular plate subjected to pure bending. The principle of stationary total potential energy enabled to derive the system of partial differential equations of equilibrium. The analytical solutions obtained for these structures were compared to the theoretical, numerical and experimental results.

Paczos et al. [13] considered short sandwich beams with special honeycomb structure of the core. Assumption of the "zig-zag" hypothesis of deformation of the beam plane cross section allowed to develop an analytical model. The analytical results so calculated were compared to those obtained experimentally.

Magnucki [12] presented a study on simply supported sandwich beams and I-beams of symmetrical structure, subjected to three-point bending and uniformly distributed load. Two variants of deformation of planar cross sections of the beams were taken into account: the classical "broken line" hypothesis and the nonlinear polynomial hypothesis. The differential equations of equilibrium of these structures enabled calculating their deflections with consideration of the shear effect.

The subject of the study is a simply supported sandwich plate-strip of length $L$ and width $b$ carrying the four-point bending (Fig. 1).

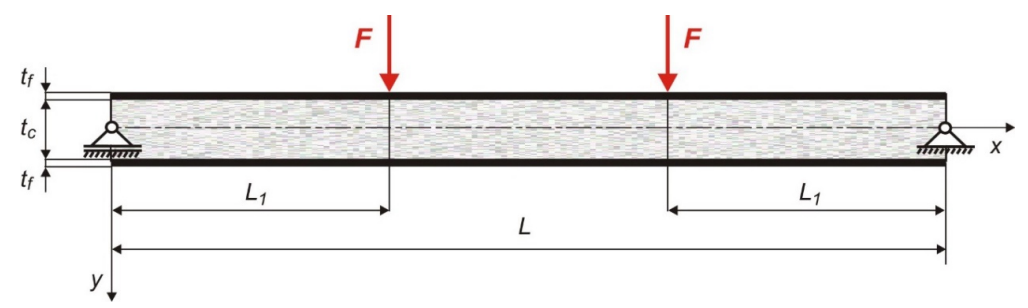

Fig. 1. Scheme of the sandwich plate-strip under four-point bending

The shear force and bending moment diagrams are shown in Fig. 2.

a) The shear force

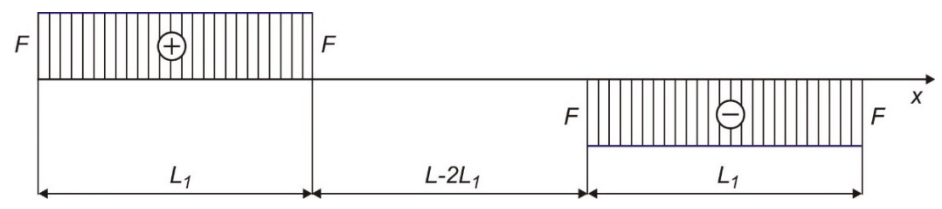

b) The bending moment

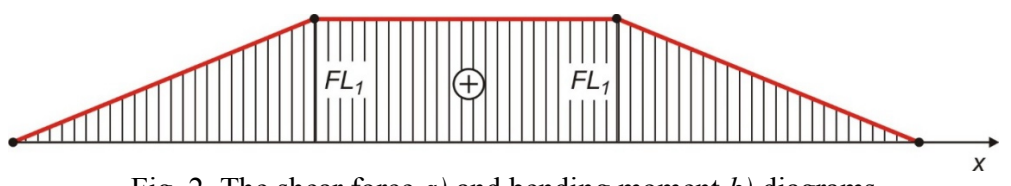

Fig. 2. The shear force $a$ ) and bending moment $b$ ) diagrams

\section{Analytical study}

The analytical model of the sandwich plate-strip is formulated based on the classical "broken-line" theory-hypothesis (Fig. 3). 


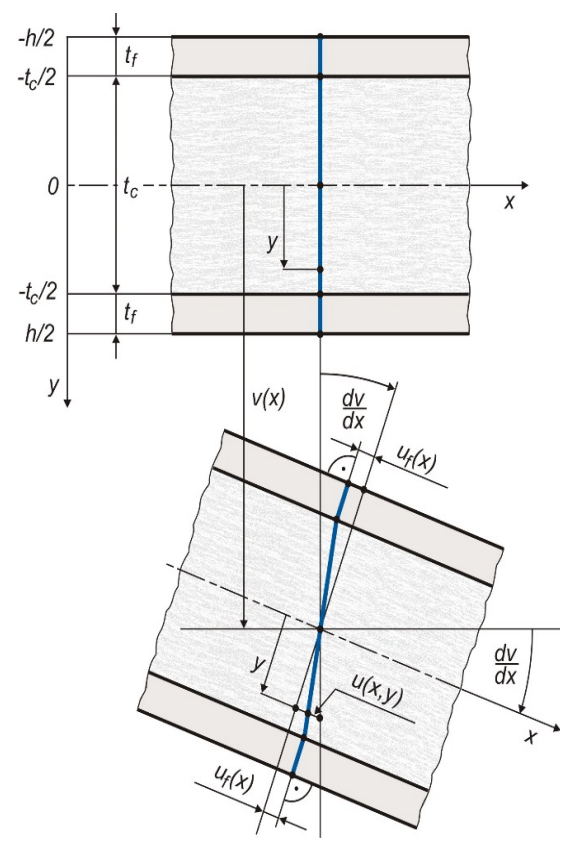

Fig. 3. Scheme of the deformation of planar cross section of the sandwich plate-strip

The longitudinal displacements in accordance with Fig. 3 are as follows:

- the upper face $\left\langle-h / 2 \leq y \leq-t_{c} / 2\right\rangle$

$$
u^{(u-f)}(x, y)=-\left[y \frac{d v}{d x}+u_{f}(x)\right],
$$

- the core $\left\langle-t_{c} / 2 \leq y \leq t_{c} / 2\right\rangle$

$$
u^{(c)}(x, y)=-y\left[\frac{d v}{d x}-2 \frac{u_{f}(x)}{t_{c}}\right],
$$

- the lower face $\left\langle t_{c} / 2 \leq y \leq h / 2\right\rangle$

$$
u^{(l-f)}(x, y)=-\left[y \frac{d v}{d x}-u_{f}(x)\right]
$$

where: $u_{f}(x)$ - longitudinal displacement of the faces, $v(x)$ - deflection, $x, y$-coordinates, $t_{f}, t_{c}-$ thicknesses of the faces and core, $h=2 t_{f}+t_{c}$ - total thickness of the plate-strip.

Therefore, the strains and stresses

- the upper face

$$
\begin{gathered}
\varepsilon_{x}^{(u-f)}(x, y)=\frac{\partial u}{\partial x}=-\left(y \frac{d^{2} v}{d x^{2}}+\frac{d u_{f}}{d x}\right), \gamma_{x y}^{(u-f)}(x, y)=\frac{\partial u}{\partial y}+\frac{d v}{d x}=0, \\
\sigma_{x}^{(u-f)}(x, y)=E_{f} \varepsilon_{x}^{(u-f)}(x, y),
\end{gathered} \begin{aligned}
\tau_{x y}^{(u-f)}(x, y) & =0,
\end{aligned}
$$

- the core

$$
\begin{array}{ll}
\varepsilon_{x}^{(c)}(x, y)=\frac{\partial u}{\partial x}=-y\left(\frac{d^{2} v}{d x^{2}}-\frac{2}{t_{c}} \frac{d u_{f}}{d x}\right), & \gamma_{x y}^{(c)}=\frac{\partial u}{\partial y}+\frac{d v}{d x}=2 \frac{u_{f}(x)}{t_{c}}, \\
\sigma_{x}^{(c)}(x, y)=E_{c} \varepsilon_{x}^{(c)}(x, y), & \tau_{x y}^{(c)}=\frac{E_{c}}{1+v_{c}} \frac{u_{f}(x)}{t_{c}},
\end{array}
$$

- the lower face

$$
\begin{array}{ll}
\varepsilon_{x}^{(l-f)}(x, y)=\frac{\partial u}{\partial x}=-\left(y \frac{d^{2} v}{d x^{2}}-\frac{d u_{f}}{d x}\right), & \gamma_{x y}^{(l-f)}(x, y)=\frac{\partial u}{\partial y}+\frac{d v}{d x}=0, \\
\sigma_{x}^{(l-f)}(x, y)=E_{f} \varepsilon_{x}^{(l-f)}(x, y), & \tau_{x y}^{(l-f)}(x, y)=0,
\end{array}
$$


where: $E_{f}, E_{c}, v_{c}$ - material constants (Young's moduli and Poisson ratio of the core).

The bending moment

$$
M_{b}(x)=b\left\{\int_{-h / 2}^{-t_{c} / 2} y \sigma_{x}^{(u-f)}(x, y) d y+\int_{-t_{c} / 2}^{t_{c} / 2} y \sigma_{x}^{(c)}(x, y) d y+\int_{t_{c} / 2}^{h / 2} y \sigma_{x}^{(l-f)}(x, y) d y\right\},
$$

where: $b$ - width.

Substituting the expressions for normal stresses (5), (7), (9) into the equation (10) and integrating, one obtains

$$
C_{v v} \frac{d^{2} v}{d x^{2}}-2 C_{v u} \frac{1}{t_{c}} \frac{d u_{f}}{d x}=-12 \frac{M_{b}(x)}{E_{c} b t_{c}^{3}}
$$

where: $C_{v v}=1+2 e_{f}\left(3+6 \chi_{f}+4 \chi_{f}^{2}\right) \chi_{f}, \quad C_{v u}=1+6 e_{f}\left(1+\chi_{f}\right) \chi_{f}$ - coefficients,

$$
e_{f}=E_{f} / E_{c}, \chi_{f}=t_{f} / t_{c} \text { - dimensionless parameters. }
$$

The transverse-shear force with consideration of the shear stress (7) is as follows

$$
T(x)=b \int_{-t_{c} / 2}^{t_{c} / 2} \tau_{x y}^{(c)}(x, y) d y=\frac{E_{c} b}{1+v_{c}} u_{f}(x) .
$$

Hence, the unknown function of the longitudinal displacement

$$
u_{f}(x)=\left(1+v_{c}\right) \frac{T(x)}{E_{c} b} .
$$

The bending problem of the sandwich plate-strip is described in two intervals:

1) $0 \leq x \leq L_{1}$ - the edge part (the bending with shear effect)

The transverse-shear force is assumed in the following form

$$
T(x)=\frac{1}{\tanh (k)} \tanh \left[k\left(1-\frac{x}{L_{1}}\right)\right] F,
$$

where: $k$ - coefficient $(k \rightarrow \infty)$.

The bending moment $M_{b}(x)=F x$.

The equation (11), after first integration with consideration of the above expression (14), is as follows

$$
C_{v v} \frac{d v}{d x}=C_{1}+2\left(1+v_{c}\right) \frac{C_{v u}}{\tanh (k)} \tanh \left[k\left(1-\frac{x}{L_{1}}\right)\right] \frac{F}{E_{c} b t_{c}}-6 x^{2} \frac{F}{E_{c} b t_{c}^{3}},
$$

where: $C_{1}$ - integration constant.

The condition for $x=L_{1}$ :

$$
\left.C_{v v} \frac{d v}{d x}\right|_{L_{1}}=C_{1}-6 \frac{F L_{1}^{2}}{E_{c} b t_{c}^{3}}
$$

The equation (15) after integration takes the following form

$$
C_{v v} v(x)=C_{2}+C_{1} x-2\left(1+v_{c}\right) \frac{C_{v u}}{k \tanh (k)} \ln \left\{\cosh \left[k\left(1-\frac{x}{L_{1}}\right)\right]\right\} \frac{F L_{1}}{E_{c} b t_{c}}-2 x^{3} \frac{F}{E_{c} b t_{c}^{3}},
$$

where: $C_{2}$ - integration constant.

The condition for $x=0, v(0)=0$, from which 
$C_{2}=2\left(1+v_{c}\right) \frac{\ln [\cosh (k)]}{k \tanh (k)} C_{v u} \frac{F L_{1}}{E_{c} b t_{c}}$, taking into account that $\lim _{k \rightarrow \infty} \frac{\ln [\cosh (k)]}{k \tanh (k)}=1$.

Therefore

$$
C_{2}=2\left(1+v_{c}\right) C_{v u} \frac{F L_{1}}{E_{c} b t_{c}} .
$$

Thus, the deflection of the first part-i.e. edge part for $x=L_{1}$ is as follows

$$
C_{v v} v\left(L_{1}\right)=2\left(1+v_{c}\right) C_{v u} \frac{F L_{1}}{E_{c} b t_{c}}+C_{1} L_{1}-2 \frac{F L_{1}^{3}}{E_{c} b t_{c}^{3}} .
$$

1) $L_{1} \leq x \leq L / 2$ - the middle part (the pure bending, without shear effect)

The transverse-shear force $T(x)=0$, the bending moment $M_{b}(x)=F L_{1}$. Therefore, the equation (11) after integration takes the following form

$$
C_{v v} \frac{d v}{d x}=C_{3}-12 x \frac{F L_{1}}{E_{c} b t_{c}^{3}},
$$

where: $C_{3}$ - integration constant.

Two conditions for the slope of the deflection curve:

- for $x=L / 2,\left.\quad C_{v v} \frac{d v}{d x}\right|_{L / 2}=0$, from which $C_{3}=6 \frac{F L_{1} L}{E_{c} b t_{c}^{3}}$,

- for $x=L_{1},\left.\quad C_{v v} \frac{d v}{d x}\right|_{L_{1}}=C_{3}-12 \frac{F L_{1}^{2}}{E_{c} b t_{c}^{3}}$,

therefore

$$
\left.C_{v v} \frac{d v}{d x}\right|_{L_{1}}=6\left(L-2 L_{1}\right) \frac{F L_{1}}{E_{c} b t_{c}^{3}} .
$$

The equation (20) after integration takes the following form

$$
C_{v v} v(x)=C_{4}+6 x \frac{F L_{1} L}{E_{c} b t_{c}^{3}}-6 x^{2} \frac{F L_{1}}{E_{c} b t_{c}^{3}},
$$

where: $C_{4}$ - integration constant.

The deflection for $x=L_{1}$ is as follows

$$
C_{v v} v\left(L_{1}\right)=C_{4}+6\left(L-L_{1}\right) \frac{F L_{1}^{2}}{E_{c} b t_{c}^{3}} .
$$

Taking into account the compatibility condition of the deflection curve slope (the expressions (16) and (21)), one obtains the integration constant

$$
C_{1}=6\left(L-L_{1}\right) \frac{F L_{1}}{E_{c} b t_{c}^{3}} .
$$

Similarly, the compatibility condition of the deflection (the expressions (19) and (23)) provides the integration constant

$$
C_{4}=2\left(1+v_{c}\right) C_{v u} \frac{F L_{1}}{E_{c} b t_{c}}-2 \frac{F L_{1}^{3}}{E_{c} b t_{c}^{3}} .
$$

Therefore, the deflection of the sandwich plate-strip for $x=L_{1}(23)$ is as follows

$$
v\left(L_{1}\right)=2\left[\left(1+v_{c}\right) C_{v u}+\left(3-4 \alpha_{1}\right) \alpha_{1} \lambda^{2}\right] \alpha_{1} \frac{\lambda}{C_{v v}} \frac{F}{E_{c} b},
$$


where: $\alpha_{1}=L_{1} / L, \lambda=L / t_{c}-$ dimensionless coefficients.

Thus, the maximum total deflection of the sandwich plate-strip based on the expression (22) takes the following form

$$
v_{\max }^{(\text {total })}=v\left(\frac{1}{2} L\right)=\left[2\left(1+v_{c}\right) C_{v u}+\frac{1}{2}\left(3-4 \alpha_{1}^{2}\right) \lambda^{2}\right] \alpha_{1} \frac{\lambda}{C_{v v}} \frac{F}{E_{c} b} .
$$

The maximum deflection of the middle part (Fig. 4)

$$
v_{\max }^{(m)}=v_{\max }^{(\text {total })}-v\left(L_{1}\right)=\frac{3}{2}\left(1-2 \alpha_{1}\right)^{2} \alpha_{1} \frac{\lambda^{3}}{C_{v v}} \frac{F}{E_{c} b} .
$$

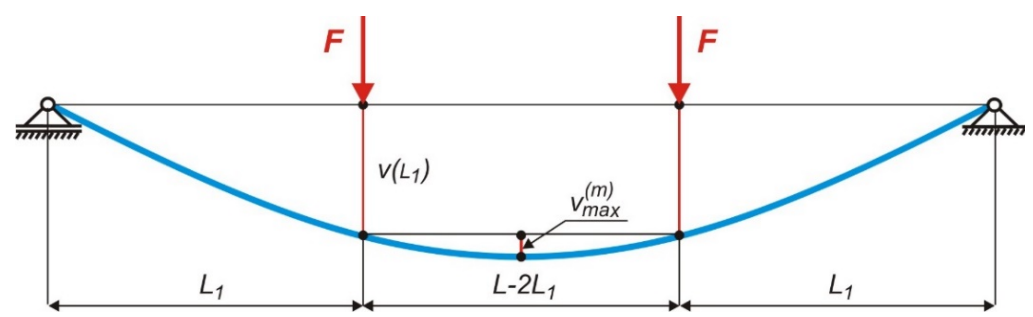

Fig. 4. Scheme of the deflection of the sandwich plate-strip under the four-point load

Example data: $L=900 \mathrm{~mm}, L_{1}=300 \mathrm{~mm}, \quad b=250 \mathrm{~mm}, \quad t_{f}=2 \mathrm{~mm}, \quad t_{c}=16 \mathrm{~mm}$, $E_{f}=70000 \mathrm{MPa}, v_{c}=0.3, E_{c}=3640 \mathrm{MPa}$, and force $F=F_{0} / 2=1500 \mathrm{~N}\left(F_{0}=3000 \mathrm{~N}-\right.$ the total load). Therefore, the maximum deflection of the middle part (28) $v_{\max }^{(m)}=0.82 \mathrm{~mm}$, the maximum total deflection (27) $v_{\max }^{(\text {total })}=6.37 \mathrm{~mm}$, and (26) $v\left(L_{1}\right)=5.55 \mathrm{~mm}$ in the point of force $F$ application.

\section{FEM-numerical study}

The FEM model of the sandwich plate-strip is developed with the use of the SolidWorks software package. Symmetry of the plate-strip allows to confine the model to a quarter of the whole structure (Fig. 5). Its proper behavior is ensured by the boundary conditions imposed on it. The plate-strip model is divided into about 942 thousand 3D tetrahedral finite elements with 4 Jacobian points. Number of the FEM nodes amounted nearly to 1400000 . Example of a part of the mesh is shown in Fig. 6.

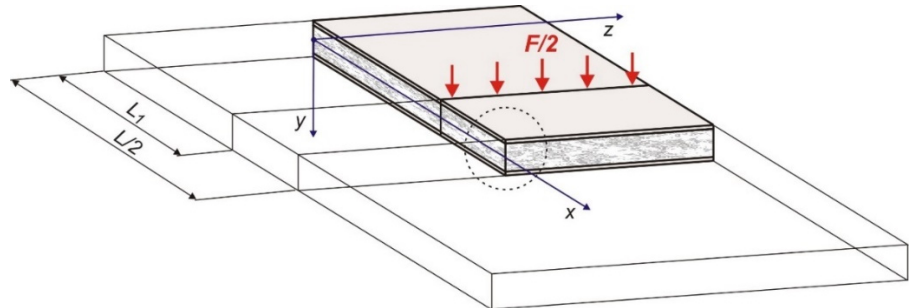

Fig. 5. A model of the sandwich plate-strip used for FEM computation

The plate-strip is located in a Cartesian coordinate system $x, y, z$. The $x z$ plane is the middle plane of the strip, equivalent to its neutral plane. The $y$-axis points downward (Fig. 5).

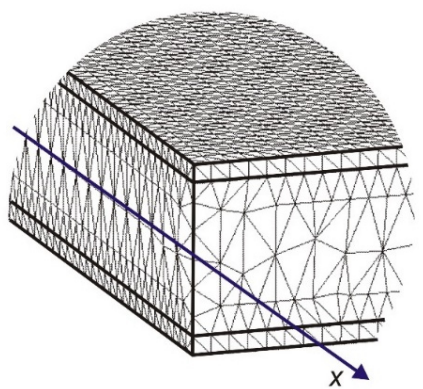

Fig. 6. A part of the FEM mesh (limited approximately to the area marked with the dotted circle in Fig. 5) 
The boundary conditions listed below, applied to the surfaces of the plate-strip model, guarantee that it behaves as one fourth of the whole strip:

- The strip model is simply supported at its edge for $x=0$. Hence, the $y$ displacements of the wall coplanar with the $y z$ - plane are zero.

- The $x$ displacements of the middle wall of the strip, parallel to the $y z$ - plane (for $x=L / 2$ ), are equal to zero.

- The $z$ displacements of the model wall coplanar with the $x y$-plane (for $z=0$ ) are zeroed.

Calculation of the bending process with the data equal to those adopted in case of the former analytical approach gave the results $v_{\max }^{(\text {total })}=6.27 \mathrm{~mm}$ and $v\left(L_{1}\right)=5.46 \mathrm{~mm}$. Thus, the maximum deflection of the middle part amounted to $v_{\max }^{(m)}=0.81 \mathrm{~mm}$.

\section{Experimental study}

The experimental tests have been made with the samples manufactured and delivered by Havel Metal Foam GmbH (Germany). The sample is shown in Fig. 7.

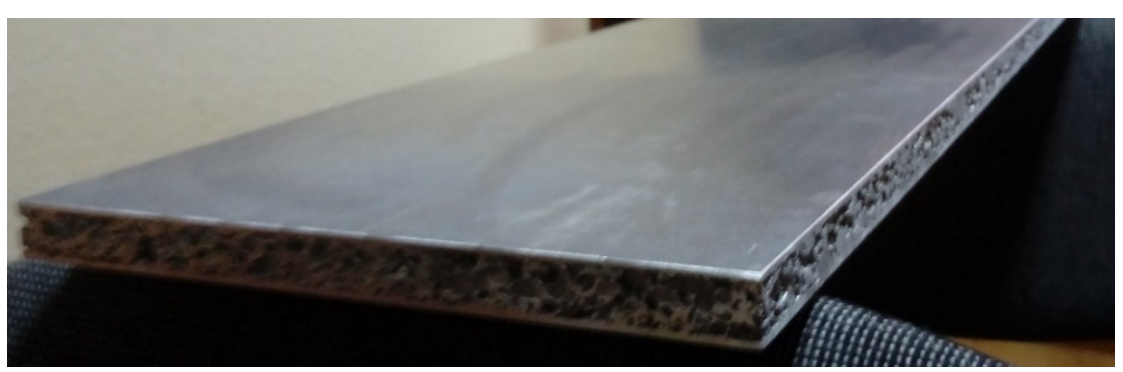

Fig. 7. Photo of the sandwich plate-strip sample

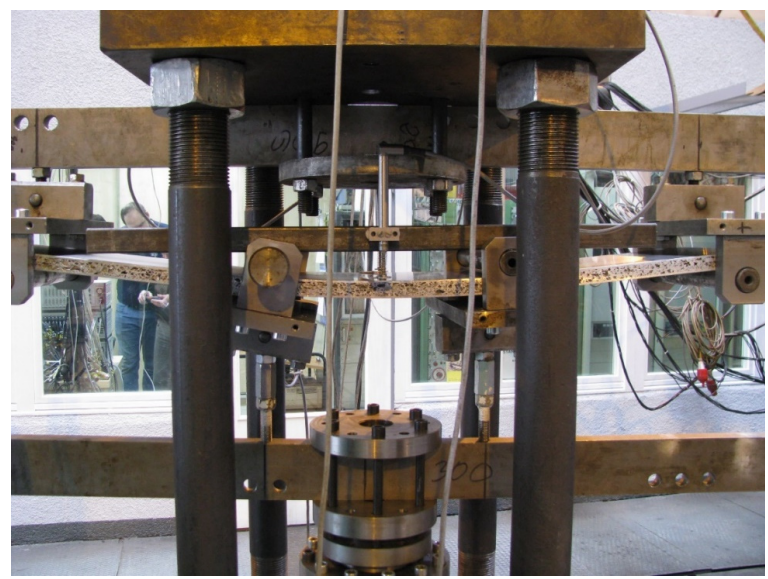

Fig. 8. The bent sample mounted on test stand (the the Łukasiewicz Research Network - RVI "TABOR” Laboratory)

The sample is mounted on the test stand and loaded with the force $F_{0}=2 F$, as shown in Fig. 1. Actual sample length amounts to $1000 \mathrm{~mm}$. It is supported on the rollers the span of which is equal to $L=900 \mathrm{~mm}$. The load is applied by two another pressure rollers spaced at $300 \mathrm{~mm}$, symmetrically with respect to the sample. In result the sample part between these two pressure rollers is subjected to pure bending (Fig. 8).

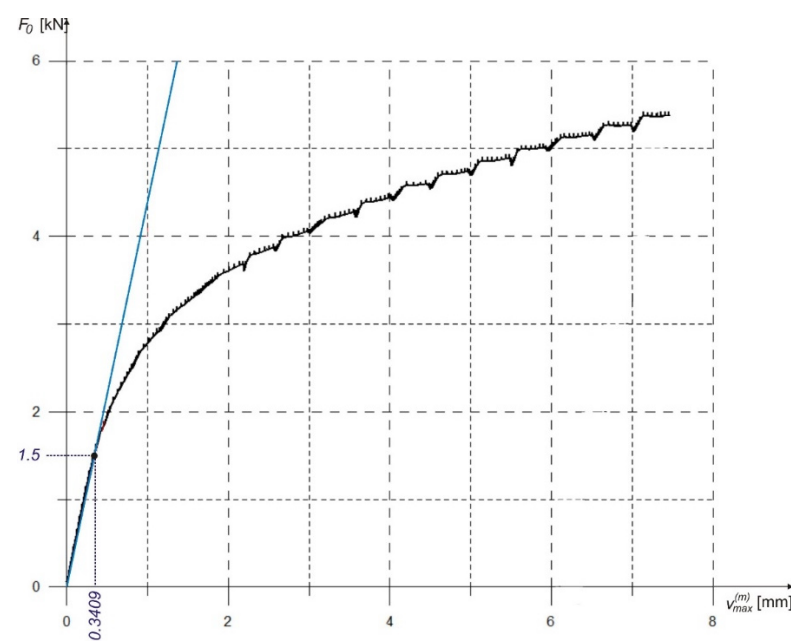

Fig. 8. The bent sample mounted on test stand (the the Łukasiewicz Research Network - RVI “TABOR” Laboratory) 
The test allowed to measure the relationship between the load $F_{0}$ and maximum deflection $v_{\max }^{(m)}$ of the sample middle point (shown in Fig. 9).

It may be noticed, that the elastic (proportionality) range is observed for the load up to $1.5 \mathrm{kN}$. Such a force causes the maximum deflection of the sample middle point $v_{\max }^{(m)}=0.3409 \mathrm{~mm}$. Further growth of the load results in evident loss of proportionality. Irregularities of the curve suggest that the material undergoes gradual destruction.

For purposes of analytical and FEM numerical tests, the total load value $F_{0}=3000 \mathrm{kN}$ was adopted. During the bench tests it was found that the elastic range of the strip sample bending reaches the value $F_{0} \leq 1.5 \mathrm{kN}$. Thus, the analytically and numerically determined maximum deflection values of the sample middle part FEM in case of this load are equal and amount to $0.41 \mathrm{~mm}$. They exceed the values measured experimentally by $20 \%$. It should be noticed that deflection of the sample central part is equal to the difference between the total deflection and the one arising in the point of application of the force-load (Fig. 4). In consequence, its value is small as compared to the deflection in the load point $(\sim 15 \%)$.

The Havel Metal Foam GmbH uses the manufacturing technology of the three-layer structures with an aluminum foam core for production of many various structural components. The above mentioned sandwich panels could be used as parts of the floor or rail vehicle paneling. Several examples of applications of these elements manufactured by Havel Metal Foam GmbH are shown in Figs. $10 \div 12$.
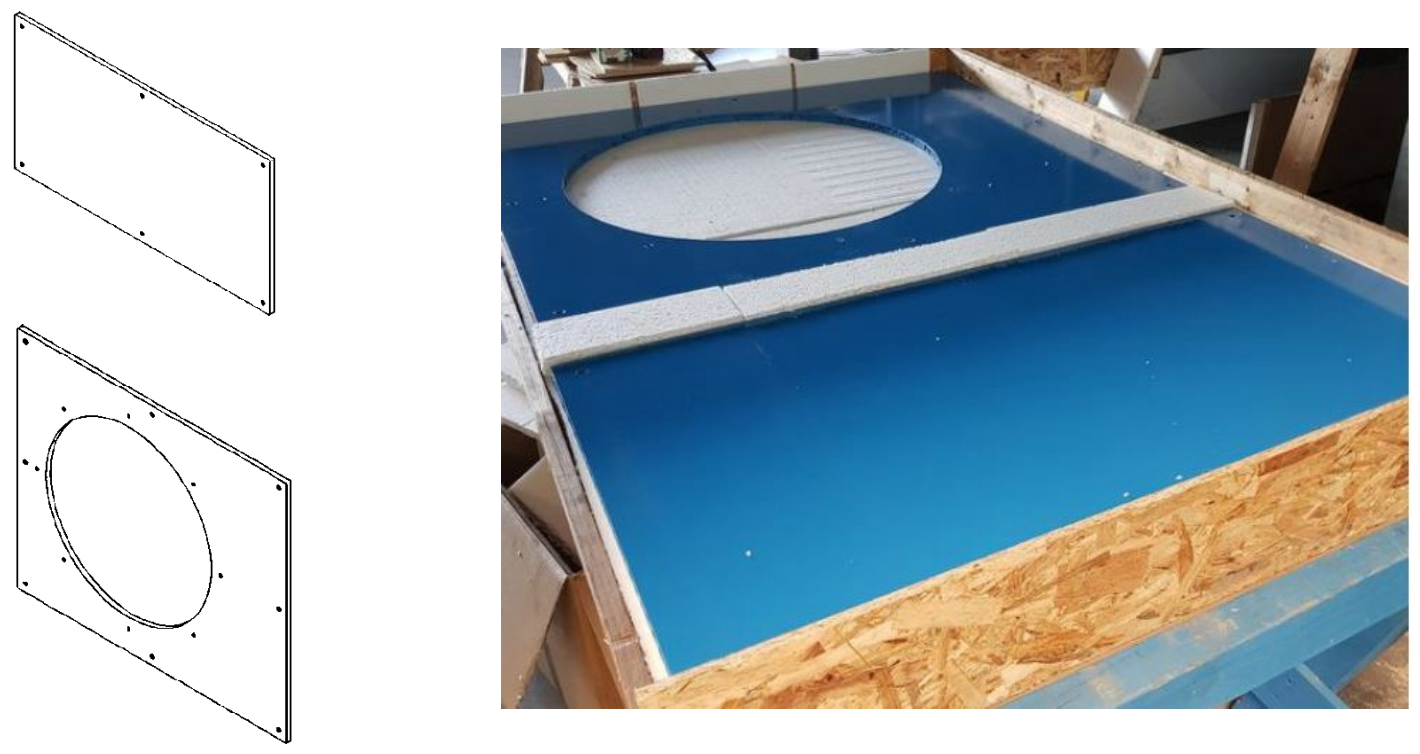

Total thickness: $20 \mathrm{~mm}$ Cover sheet (top): $1.5 \mathrm{~mm}$ Metal foam core: $17 \mathrm{~mm}$ Cover sheet (bottom): $1.5 \mathrm{~mm}$
Grubość całkowita: $20 \mathrm{~mm}$ Okładzina górna: $1.5 \mathrm{~mm}$ Rdzeń z piany metalowej: $17 \mathrm{~mm}$ Okładzina dolna: $1.5 \mathrm{~mm}$

Fig. 10. Compressor housing cover

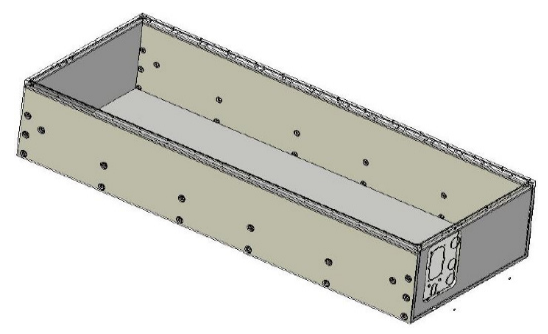

Welded construction $1515 \times 600 \times 298 \mathrm{~mm}$ with integrated $\varnothing 8$ cooling tube system

Konstrukcja spawana $1515 \times 600 \times 298 \mathrm{~mm}$ ze zintegrowanym układem rur chłodzących

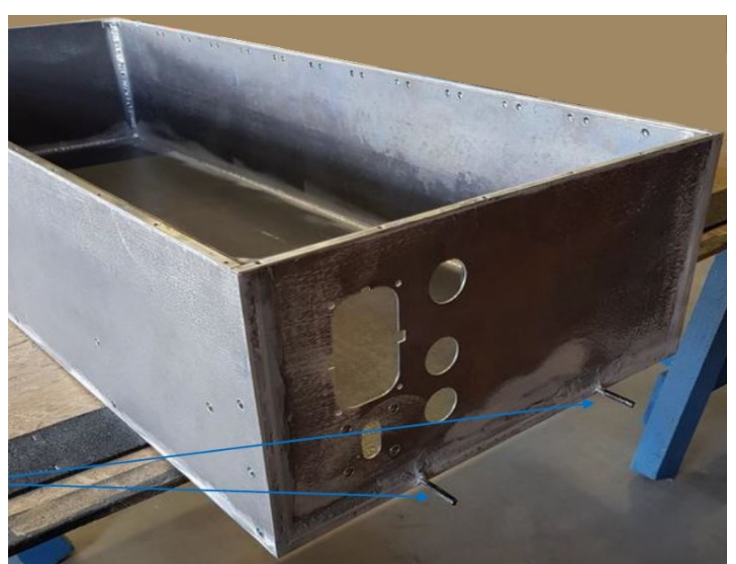

Fig. 11. A case for a $600 \mathrm{~V}$ battery system of the electric vehicles 

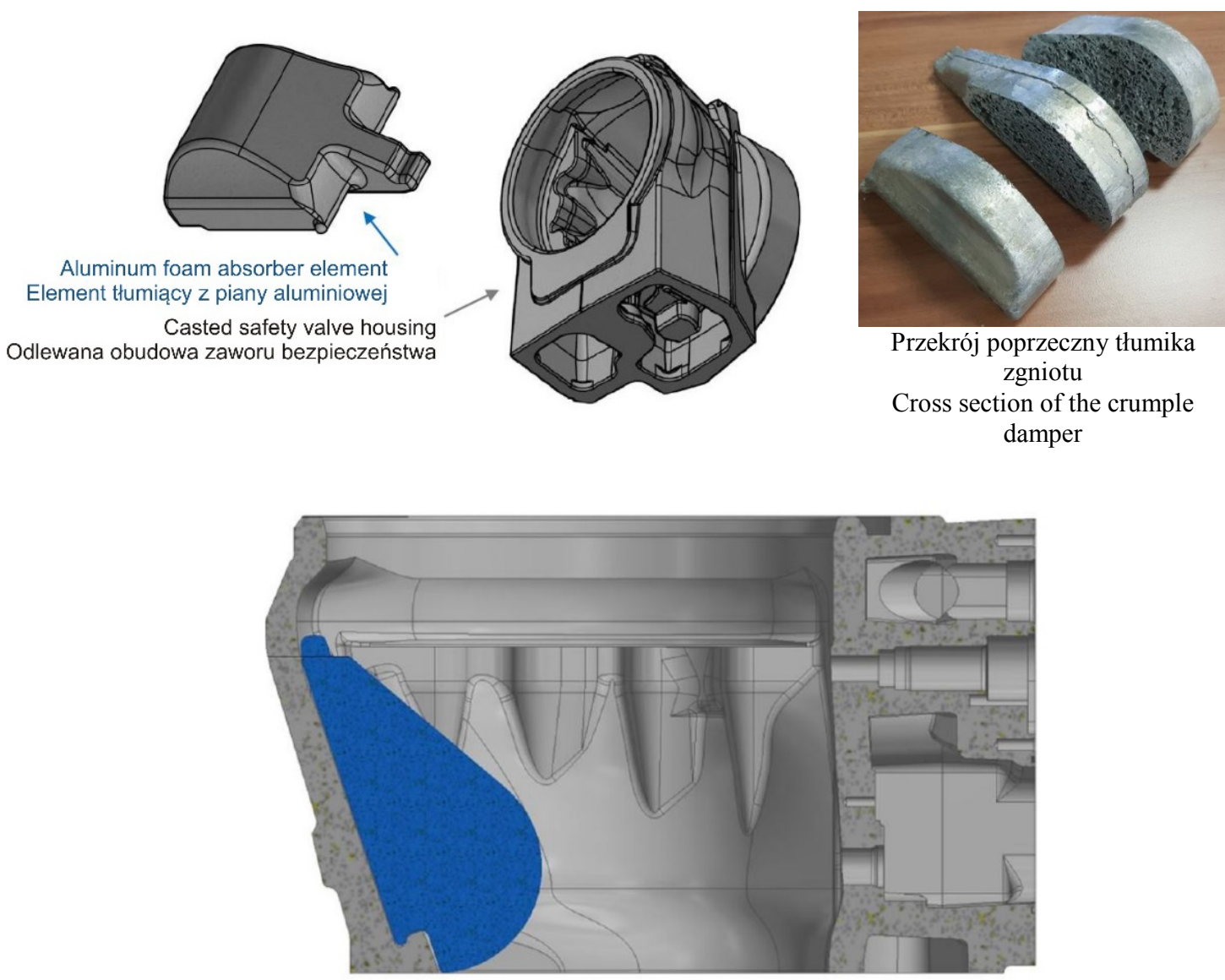

The absorber element inside the casted safety valve housing Element tłumiący wewnątrz obudowy zaworu bezpieczeństwa

Fig. 12. Crumple damper of a 5" safety valve

It may be assumed that the use of three-layer structures with an aluminum foam core should expand. Such structures have many advantages, they are distinguished by low mass, maintaining the required strength. They also have valuable properties in case of impact loads.

\section{Conclusions}

The deflections of the sample strip have been determined with three methods: analytically, FEM numerically and experimentally. For purposes of the first two approaches the Young's moduli of the faces and the core have been arbitrarily adopted as $E_{f}=72000$ (aluminium) $\mathrm{MPa}, E_{c}=3640 \mathrm{MPa}$ (equivalent value for the aluminium foam) and the Poisson ratio of the core $v_{c}=0.3$. Comparison of these two solutions is satisfactory, the deflections well match with each other (Table 1).

Nevertheless, in the laboratory test only the maximum deflection of the sample middle point was measured and gave a result deviating by around $20 \%$ from that determined with two above solutions. Moreover, in case of the load equal to $F_{0}=3000 \mathrm{~N}$ the foam material enters a plastic range, that does not occur in the equivalent material having the trial Young's modulus $E_{c}$.

Comparison of the results obtained in analytical, FEM-numerical and experimental approaches

Table 1.

\begin{tabular}{|c|c|c|c|}
\hline Method & Analytical & FEM-numerical & Experimental \\
\hline$F_{0}[\mathrm{kN}]$ & - & 3.0 & - \\
\hline$v_{\max }^{(\text {total }}[\mathrm{mm}]$ & 6.91 & 7.00 & - \\
\hline$v\left(L_{1}\right)[\mathrm{mm}]$ & 6.04 & 6.12 & 0.3409 \\
\hline$v_{\max }^{(m)}[\mathrm{mm}]$ & 0.87 & 0.88 & 4.400 \\
\hline$k(29)[\mathrm{kN} / \mathrm{mm}]$ & 3.488 & 3.409 & - \\
\hline
\end{tabular}

Deflection of the central part of the sample, equal to the difference between the total deflection and the maximum deflection in the load application point (Fig. 4), is small and amounts about to $15 \%$ of the deflection in the load point. 


\section{Bibliography}

[1] Banhart J., Manufacture, characterisation and application of cellular metals and metal foams, Progress in Material Science, 46(6): 559-632, 2001.

[2] Icardi U., Applications of Zig-Zag theories to sandwich beams, Mechanics of Advanced Materials and Structures. 10(1): 77-97, 2003.

[3] Jasion P., Magnucki K., Face wrinkling of sandwich beams under pure bending, Journal of Theoretical and Applied Mechanics, 50(4): 933-941, 2012.

[4] Jasion P., Magnucka-Blandzi E., Szyc W., Magnucki K., Global and local buckling of sandwich circular and beam-rectangular plates with metal foam core, Thin-Walled Structures, 61: 154-161, 2012.

[5] Kozak J., Stalowe panele sandwicz w konstrukcjach okrętowych, Wyd. Politechniki Gdańskiej, Gdańsk 2018.

[6] Magnucka-Blandzi E., Magnucki K., Effective design of a sandwich beam with a metal foam core, ThinWalled Structures, 45(4): 432-438, 2007.

[7] Magnucka-Blandzi E., Mathematical modelling of a rectangular sandwich plate with a metal foam core, Journal of Theoretical and Applied Mechanics, 49(2): 439-55, 2011.

[8] Magnucki K., Szyc W. (Red.), Wytrzymałość i stateczność belek, i plyt trójwarstwowych z rdzeniem z pianki aluminiowej, Wyd. Politechniki Poznańskiej, Poznań 2012.

[9] Magnucki K., Smyczynski M., Jasion P., Deflection and strength of a sandwich beam with thin binding layers between faces and a core, Archives of Mechanics, 65(4): 301-311, 2013.

[10] Magnucki K., Jasion P., Magnucka-Blandzi E., Wasilewicz P., Theoretical and experimental study of a sandwich circular plate under pure bending, Thin-Walled Structures, 79: 1-7, 2014.

[11] Magnucki K., Jasion P., Szyc W., Smyczyński M., Strength and buckling of a sandwich beam with thin binding layers between faces and a metal foam core, Steel and Composite Structures, 16(3): 325-337, 2014.

[12] Magnucki K., Bending of symmetrically sandwich beams and I-beams - Analytical study, International Journal of Mechanical Science, 150: 411-419, 2019.

[13] Paczos P., Wichniarek R., Magnucki K., Three-point bending of the sandwich beam with special structures of the core, Composite Structures, 201: 676-682, 2018.

[14] Reddy J.N., (Second Ed.), Mechanics of laminated composite plates and shells: theory and analysis, CRC Press, Boca Raton London New York Washington, 2004.

[15] Sayyad A.S., Ghugal Y.M., Bending, buckling and free vibration of laminated composite and sandwich beams: a critical review of literature, Composite Structures, 171: 486-504, 2017.

[16] Vinson J.R., Sandwich structures, Applied Mechanics Reviews, ASME, 54(3), 201-214, 2001. 


\author{
Krzysztof Magnucki \\ Łukasiewicz-IPS "TABOR" \\ Dennis Alsdorf \\ Havel Metal Foam GmbH \\ Jerzy Lewiński \\ Michat Kowalski \\ Łukasiewicz - IPS "TABOR” \\ Alexander Richter \\ Havel Metal Foam GmbH \\ Andrzej Zbierski \\ Łukasiewicz - IPS “TABOR”
}

\title{
Analityczne, numeryczne (MES) i doświadczalne badanie zginania trójwarstwowego pasma płytowego $\mathrm{z}$ rdzeniem $\mathrm{z}$ pianki metalowej
}

\begin{abstract}
Przedmiotem badań jest trójwarstwowe pasmo plytowe poddane czteropunktowemu zginaniu. Opracowano analityczny model tego pasma, korzystajac z klasycznej teorii linii tamanej nazywanej teoria Zig-Zag. W paśmie tym wyróżniono trzy przedziaty: dwa brzegowe, $w$ których występuje zginanie $i$ ścinanie oraz jeden środkowy, w którym występuje czyste zginanie. Wyznaczono calkowite ugięcie maksymalne pasma ptytowego oraz maksymalne ugięcie odcinka środkowego. Przeprowadzono obliczenia numeryczne metoda elementów skończonych (MES) dla takiego samego modelu pasma, jak wyżej wspomniany model analityczny. Próbe doświadczalna przeprowadzono na stanowisku badawczym w Instytucie Pojazdów Szynowych. Porównano wyniki badań analitycznych, numerycznych i doświadczalnych. Analizowane płyty warstwowe moga być stosowane, m. in. jako części podtogi lub poszycia pojazdu szynowego.
\end{abstract}

\section{Wstęp}

Podstawy analitycznego modelowania konstrukcji warstwowych zostały stworzone w połowie XX wieku. Vinson [16] przedstawił przegląd prac opublikowanych w XX wieku, omawiających problemy mechaniki konstrukcji warstwowych. Reddy [14] opracował obszerną monografię poświęconą kompozytowym płytom i powłokom. Opisał metody modelowania i analizy tych konstrukcji, wraz z różnymi teoriami mającymi do nich zastosowanie. Magnucki i Szyc [8] sporządzili współautorska monografię na temat wytrzymałości i stateczności belek i płyt z rdzeniem z piany aluminiowej. Kozak [5] opisał zastosowania stalowych płyt warstwowych w konstrukcji statków.

Sayyad i Ghugal [15] przedstawili krytyczny przegląd literatury opublikowanej w XXI wieku na temat konstrukcji kompozytowych i warstwowych. W tym opracowaniu przytoczono rozmaite teorie $\mathrm{i}$ hipotezy stosowane w tej dziedzinie i wyróżniono możliwy zakres przyszłych badań. Banhart [1] rozważał problemy produkcji pian metalowych i innych porowatych struktur metalowych. Autor przytacza różne innowacyjne metody produkcyjne i sposoby opisu właściwości metali komórkowych. W pracy przedstawiono również zastosowania tych materiałów $\mathrm{w}$ różnych gałęziach przemysłu. Icardi [2] opracował model przeznaczony do analizy belek warstwowych. Przemieszczenia sformułowano z myślą o spełnieniu warunków ciagłości naprężenia tnącego, normalnego i gradientu naprężenia w kierunku poprzecznym.

Hipoteza Zig-Zag poprawia dokładność takiego podejścia. Wyniki porównano $\mathrm{z}$ innymi trójwymiarowymi rozwiązaniami $\mathrm{w}$ zakresie sprężystym oraz $\mathrm{z}$ różnymi modelami dostępnymi $\mathrm{w}$ literaturze. Jasion i Magnucki [3] rozpatrywali belki warstwowe poddane czteropunktowemu zginaniu. Zasada stacjonarności całkowitej energii potencjalnej posłużyła do wyprowadzenia wzorów wyznaczających naprężenia krytyczne w okładzinach belki, wywołujące marszczenie górnej okładziny. Przedstawiono wyniki uzyskane na podstawie modelu analitycznego i za pomocą MES dla kilku belek warstwowych o różnych grubościach i właściwościach rdzenia. Jasion $i$ in. [4] badali wyboczenie globalne i lokalne okładzin belek warstwowych i warstwowych płyt kołowych. Opracowano matematyczny model przemieszczeń, z uwzględnieniem ścinania. Rozwiązania analityczne porównano $\mathrm{z}$ wynikami otrzymanymi za pomocą metody elementów skończonych $\mathrm{i}$ wynikami doświadczalnymi. Magnucka-Blandzi i Magnucki [6] analizowali swobodnie podpartą belkę warstwową z rdzeniem z piany metalowej. Nieliniowa hipoteza deformacji i twierdzenie o minimalnej całkowitej energii potencjalnej posłużyły do wyznaczenia różniczkowych równań równowagi. Ich rozwiązanie pozwoliło wyznaczyć optymalne bezwymiarowe parametry belki. 
Magnucka-Blandzi [7] rozważała swobodnie podpartą warstwową prostokątną płytę ściskaną w płaszczyźnie. Założenie definiujące pole przemieszczeń i warunki geometryczne umożliwiło wyprowadzenie układu równań różniczkowych, a następnie wyznaczenie krytycznych obciążeń dla przypadków rodziny warstwowych płyt. Magnucki $i$ in. [9], [10] i [11] analizowali konstrukcje posiadające rdzenie z piany aluminiowej. Badania były poświęcone belce pięciowarstwowej poddanej ściskaniu osiowemu lub zginaniu, oraz warstwowej płycie kołowej poddanej czystemu zginaniu. Zasada stacjonarności całkowitej energii potencjalnej posłużyła do wyprowadzenia układu cząstkowych równań różniczkowych równowagi. Rozwiązania analityczne otrzymane dla tych konstrukcji porównano z wynikami teoretycznymi, numerycznymi i doświadczalnymi.

Paczos $i$ in. [13] rozpatrywali krótkie belki warstwowe $\mathrm{z}$ rdzeniem o strukturze plastra miodu. Przyjęta hipoteza Zig-Zag deformacji płaskiego przekroju poprzecznego belki umożliwiła opracowanie modelu analitycznego. Wyniki uzyskane analitycznie porównano z doświadczalnymi.

Magnucki [12] badał swobodnie podparte belki warstwowe i dwuteowe o strukturze symetrycznej, poddane zginaniu trójpunktowemu i obciążeniu rozłożonemu. Wzięto pod uwagę dwa warianty odkształcenia płaskiego przekroju poprzecznego belek, a mianowicie klasyczną hipotezę „linii łamanej” oraz nieliniową hipotezę wielomianową. Równania różniczkowe równowagi tych struktur umożliwiły wyznaczenie ich ugięć, z uwzględnieniem ścinania.

Przedmiotem niniejszej pracy jest swobodnie podparte warstwowe pasmo płytowe o dhugości $L$ i szerokości $b$, poddane zginaniu czteropunktowemu (rys. 1).

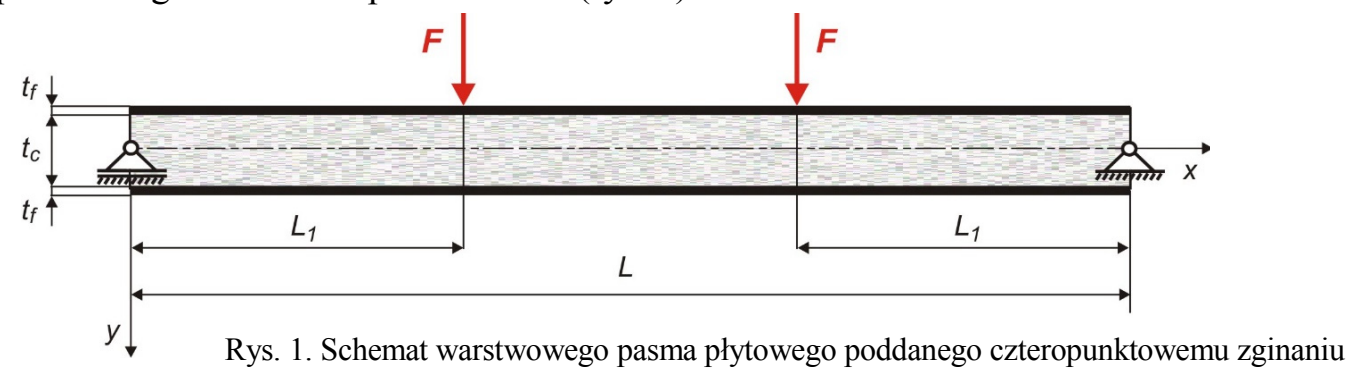

Wykresy siły tnącej i momentu gnącego są przedstawione na rys. 2.

a) Sita tnqca

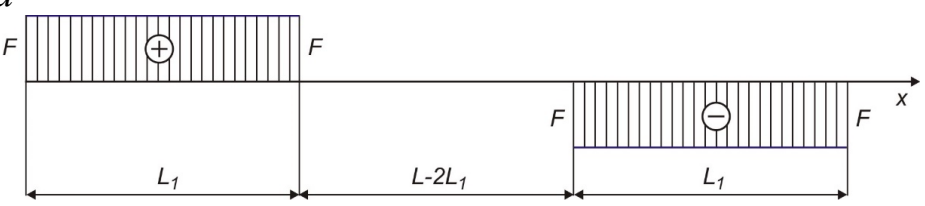

b) Moment gnacy

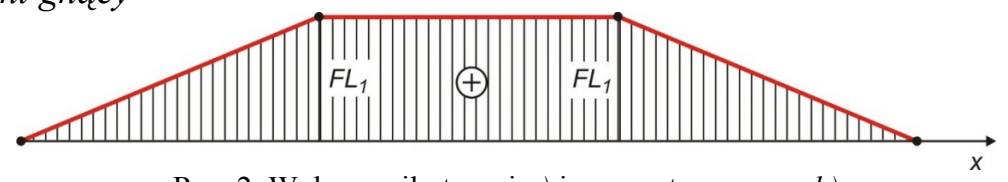

Rys. 2. Wykresy siły tnącej a) i momentu gnącego b)

\section{Badanie analityczne}

Model analityczny warstwowego pasma płytowego jest sformułowany na podstawie klasycznej hipotezy „linii łamanej” (rys. 3).

Rys. 3. Schemat odkształcenia płaskiego przekroju poprzecznego warstwowego pasma płytowego

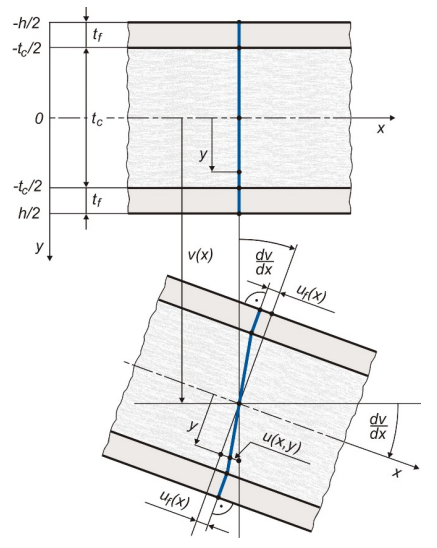


Zgodnie z rys. 3 przemieszczenie wzdłużne jest wyrażone następująco:

- okładzina górna $\left\langle-h / 2 \leq y \leq-t_{c} / 2\right\rangle$

$$
u^{(u-f)}(x, y)=-\left[y \frac{d v}{d x}+u_{f}(x)\right]
$$

- $\operatorname{rdzeń}\left\langle-t_{c} / 2 \leq y \leq t_{c} / 2\right\rangle$

$$
u^{(c)}(x, y)=-y\left[\frac{d v}{d x}-2 \frac{u_{f}(x)}{t_{c}}\right],
$$

- okładzina dolna $\left\langle t_{c} / 2 \leq y \leq h / 2\right\rangle$

$$
u^{(l-f)}(x, y)=-\left[y \frac{d v}{d x}-u_{f}(x)\right]
$$

gdzie: $u_{f}(x)$ - wzdłużne przemieszczenie okładzin, $v(x)$ - ugięcie, $x, y$ - współrzędne, $t_{f}, t_{c}$ grubości okładzin i rdzenia, $h=2 t_{f}+t_{c}$ - całkowita grubość pasma płytowego.

Odkształcenia i naprężenia zapisano zatem $\mathrm{w}$ postaci

- dla okładziny górnej

$$
\begin{array}{ll}
\varepsilon_{x}^{(u-f)}(x, y)=\frac{\partial u}{\partial x}=-\left(y \frac{d^{2} v}{d x^{2}}+\frac{d u_{f}}{d x}\right), & \gamma_{x y}^{(u-f)}(x, y)=\frac{\partial u}{\partial y}+\frac{d v}{d x}=0, \\
\sigma_{x}^{(u-f)}(x, y)=E_{f} \varepsilon_{x}^{(u-f)}(x, y), & \tau_{x y}^{(u-f)}(x, y)=0,
\end{array}
$$

- dla rdzenia

$$
\begin{array}{ll}
\varepsilon_{x}^{(c)}(x, y)=\frac{\partial u}{\partial x}=-y\left(\frac{d^{2} v}{d x^{2}}-\frac{2}{t_{c}} \frac{d u_{f}}{d x}\right), & \gamma_{x y}^{(c)}=\frac{\partial u}{\partial y}+\frac{d v}{d x}=2 \frac{u_{f}(x)}{t_{c}}, \\
\sigma_{x}^{(c)}(x, y)=E_{c} \varepsilon_{x}^{(c)}(x, y), & \tau_{x y}^{(c)}=\frac{E_{c}}{1+v_{c}} \frac{u_{f}(x)}{t_{c}}
\end{array}
$$

- dla okładziny dolnej

$$
\begin{array}{ll}
\varepsilon_{x}^{(l-f)}(x, y)=\frac{\partial u}{\partial x}=-\left(y \frac{d^{2} v}{d x^{2}}-\frac{d u_{f}}{d x}\right), & \gamma_{x y}^{(l-f)}(x, y)=\frac{\partial u}{\partial y}+\frac{d v}{d x}=0, \\
\sigma_{x}^{(l-f)}(x, y)=E_{f} \varepsilon_{x}^{(l-f)}(x, y), & \tau_{x y}^{(l-f)}(x, y)=0,
\end{array}
$$

gdzie: $E_{f}, E_{c}, v_{c}$-stałe materiałowe (moduły Younga i liczba Poissona rdzenia).

Moment gnący

$$
M_{b}(x)=b\left\{\int_{-h / 2}^{-t_{c} / 2} y \sigma_{x}^{(u-f)}(x, y) d y+\int_{-t_{c} / 2}^{t_{c} / 2} y \sigma_{x}^{(c)}(x, y) d y+\int_{t_{c} / 2}^{h / 2} y \sigma_{x}^{(l-f)}(x, y) d y\right\},
$$

gdzie: $b$ - szerokość.

Podstawiając wyrażenia (5), (7), (9) określające naprężenia normalne do równania (10) i całkując, otrzymano

$$
C_{v v} \frac{d^{2} v}{d x^{2}}-2 C_{v u} \frac{1}{t_{c}} \frac{d u_{f}}{d x}=-12 \frac{M_{b}(x)}{E_{c} b t_{c}^{3}},
$$

gdzie: $C_{v v}=1+2 e_{f}\left(3+6 \chi_{f}+4 \chi_{f}^{2}\right) \chi_{f}, \quad C_{v u}=1+6 e_{f}\left(1+\chi_{f}\right) \chi_{f}-$ współczynniki, $e_{f}=E_{f} / E_{c}, \chi_{f}=t_{f} / t_{c}$ - parametry bezwymiarowe. 
Uwzględniając naprężenie tnące (7), otrzymano poprzeczną siłę styczną w następującej postaci

$$
T(x)=b \int_{-t_{c} / 2}^{t_{c} / 2} \tau_{x y}^{(c)}(x, y) d y=\frac{E_{c} b}{1+v_{c}} u_{f}(x) .
$$

Zatem nieznana funkcja przemieszczenia wzdłużnego wynosi

$$
u_{f}(x)=\left(1+v_{c}\right) \frac{T(x)}{E_{c} b} .
$$

Problem zginania warstwowego pasma płytowego jest sformułowany w dwóch przedziałach:

1) $0 \leq x \leq L_{1}$ - część przylegająca do krawędzi (zginanie z efektem ścinania)

Przyjęto następującą postać poprzecznej siły stycznej

$$
T(x)=\frac{1}{\tanh (k)} \tanh \left[k\left(1-\frac{x}{L_{1}}\right)\right] F
$$

gdzie: $k$-współczynnik $(k \rightarrow \infty)$.

Moment gnący $M_{b}(x)=F x$.

Równanie (11) po jednokrotnym scałkowaniu i uwzględnieniu powyższego wyrażenia (14) przybiera postać następującą

$$
C_{v v} \frac{d v}{d x}=C_{1}+2\left(1+v_{c}\right) \frac{C_{v u}}{\tanh (k)} \tanh \left[k\left(1-\frac{x}{L_{1}}\right)\right] \frac{F}{E_{c} b t_{c}}-6 x^{2} \frac{F}{E_{c} b t_{c}^{3}},
$$

gdzie: $C_{1}-$ stała całkowania.

Warunek dla $x=L_{1}$ :

$$
\left.C_{v v} \frac{d v}{d x}\right|_{L_{1}}=C_{1}-6 \frac{F L_{1}^{2}}{E_{c} b t_{c}^{3}} .
$$

Równanie (15) po scałkowaniu ma postać następującą

$$
C_{v v} v(x)=C_{2}+C_{1} x-2\left(1+v_{c}\right) \frac{C_{v u}}{k \tanh (k)} \ln \left\{\cosh \left[k\left(1-\frac{x}{L_{1}}\right)\right]\right\} \frac{F L_{1}}{E_{c} b t_{c}}-2 x^{3} \frac{F}{E_{c} b t_{c}^{3}},
$$

gdzie: $C_{2}$ - stała całkowania.

Warunek dla $x=0, v(0)=0$, a stąd

$C_{2}=2\left(1+v_{c}\right) \frac{\ln [\cosh (k)]}{k \tanh (k)} C_{v u} \frac{F L_{1}}{E_{c} b t_{c}}$, biorąc pod uwage, że $\lim _{k \rightarrow \infty} \frac{\ln [\cosh (k)]}{k \tanh (k)}=1$.

W rezultacie

$$
C_{2}=2\left(1+v_{c}\right) C_{v u} \frac{F L_{1}}{E_{c} b t_{c}} .
$$

Ugięcie w pierwszym przedziale - tzn. przylegającym do krawędzi dla $x=L_{1}$, jest zatem następujące:

$$
C_{v v} v\left(L_{1}\right)=2\left(1+v_{c}\right) C_{v u} \frac{F L_{1}}{E_{c} b t_{c}}+C_{1} L_{1}-2 \frac{F L_{1}^{3}}{E_{c} b t_{c}^{3}} .
$$

2) $L_{1} \leq x \leq L / 2$ - część środkowa (czyste zginanie, bez ścinania)

Poprzeczna siła styczna $T(x)=0$, moment gnący $M_{b}(x)=F L_{1}$. Równanie (11) po scałkowaniu przyjmuje zatem postać

$$
C_{v v} \frac{d v}{d x}=C_{3}-12 x \frac{F L_{1}}{E_{c} b t_{c}^{3}}
$$


gdzie: $C_{3}$ - stała całkowania.

Przyjęto dwa warunki odnoszące się do nachylenia krzywej ugięcia:

- dla $x=L / 2,\left.\quad C_{v v} \frac{d v}{d x}\right|_{L / 2}=0$, skąd $C_{3}=6 \frac{F L_{1} L}{E E_{c} b t_{c}^{3}}$,

- dla $x=L_{1},\left.\quad C_{v v} \frac{d v}{d x}\right|_{L_{1}}=C_{3}-12 \frac{F L_{1}^{2}}{E_{c} b t_{c}^{3}}$,

zatem

$$
\left.C_{v v} \frac{d v}{d x}\right|_{L_{1}}=6\left(L-2 L_{1}\right) \frac{F L_{1}}{E_{c} b t_{c}^{3}} .
$$

Równanie (20) po scałkowaniu przyjmuje postać

$$
C_{v v} v(x)=C_{4}+6 x \frac{F L_{1} L}{E_{c} b t_{c}^{3}}-6 x^{2} \frac{F L_{1}}{E_{c} b t_{c}^{3}},
$$

gdzie: $C_{4}-$ stała całkowania.

Ugięcie dla $x=L_{1}$ wyraża się następująco

$$
C_{v v} v\left(L_{1}\right)=C_{4}+6\left(L-L_{1}\right) \frac{F L_{1}^{2}}{E_{c} b t_{c}^{3}} .
$$

Uwzględniając warunek zgodności nachylenia krzywej ugięcia (wyrażenia (16) i (21)) otrzymuje się stałą całkowania

$$
C_{1}=6\left(L-L_{1}\right) \frac{F L_{1}}{E_{c} b t_{c}^{3}} .
$$

Podobnie, warunek zgodności ugięć (wyrażenia (19) i (23)) pozwala wyznaczyć stałą całkowania

$$
C_{4}=2\left(1+v_{c}\right) C_{v u} \frac{F L_{1}}{E_{c} b t_{c}}-2 \frac{F L_{1}^{3}}{E_{c} b t_{c}^{3}} .
$$

Zatem ugięcie warstwowego pasma płytowego dla $x=L_{1}$ (23) jest postaci

$$
v\left(L_{1}\right)=2\left[\left(1+v_{c}\right) C_{v u}+\left(3-4 \alpha_{1}\right) \alpha_{1} \lambda^{2}\right] \alpha_{1} \frac{\lambda}{C_{v v}} \frac{F}{E_{c} b},
$$

gdzie: $\alpha_{1}=L_{1} / L, \lambda=L / t_{c}-$ współczynniki bezwymiarowe.

Tak więc, zgodnie z wyrażeniem (22), całkowite maksymalne ugięcie warstwowego pasma płytowego

$$
v_{\max }^{\text {(total })}=v\left(\frac{1}{2} L\right)=\left[2\left(1+v_{c}\right) C_{v u}+\frac{1}{2}\left(3-4 \alpha_{1}^{2}\right) \lambda^{2}\right] \alpha_{1} \frac{\lambda}{C_{v v}} \frac{F}{E_{c} b} .
$$

Natomiast maksymalne ugięcie części środkowej (rys. 4)

$$
v_{\max }^{(m)}=v_{\max }^{(\text {total })}-v\left(L_{1}\right)=\frac{3}{2}\left(1-2 \alpha_{1}\right)^{2} \alpha_{1} \frac{\lambda^{3}}{C_{v v}} \frac{F}{E_{c} b} .
$$

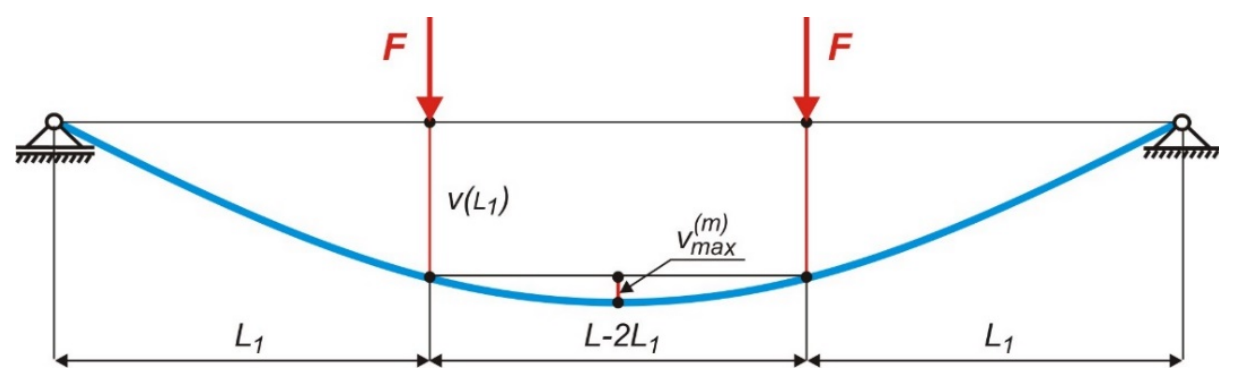

Rys. 4. Schemat ugięcia pasma płytowego poddanego czteropunktowemu zginaniu 
Przykładowe obliczenia wykonano dla następujących danych: $L=900 \mathrm{~mm}, L_{I}=300 \mathrm{~mm}, b=250 \mathrm{~mm}$, $t_{f}=2 \mathrm{~mm}, t_{c}=16 \mathrm{~mm}, E_{f}=72000 \mathrm{MPa}, E_{c}=3640 \mathrm{MPa}, v_{c}=0.3$ oraz wartość siły $F=F_{0} / 2=1500 \mathrm{~N}$ $\left(F_{0}=2 F=3000 \mathrm{~N}\right.$ - obciążenie całkowite). Otrzymano zatem maksymalne ugięcie części środkowej (28) $v_{\max }^{(m)}=0.82 \mathrm{~mm}$, maksymalne ugięcie całkowite $(27) v_{\max }^{(\text {total })}=6.37 \mathrm{~mm}$ oraz ugięcie $\mathrm{w}$ miejscu przyłożenia siły $F$, wyrażenie (26), $v\left(L_{1}\right)=5.55 \mathrm{~mm}$.

\section{Badanie numeryczne MES}

Model warstwowego pasma płytowego przeznaczony do analizy metodą elementów skończonych został opracowany za pomocą pakietu SolidWorks. Symetria pasma płytowego pozwala ograniczyć ten model do jednej czwartej całego pasma (rys. 5). Jego właściwe zachowanie zapewniają nałożone nań odpowiednie warunki brzegowe. Model pasma płytowego jest podzielony na około 942 tysiące 3wymiarowych czworościennych elementów skończonych, z czterema punktami Jakobianu. Liczba węzłów jest bliska 1400 000. Przykładowy fragment siatki jest pokazany na rys. 6 .

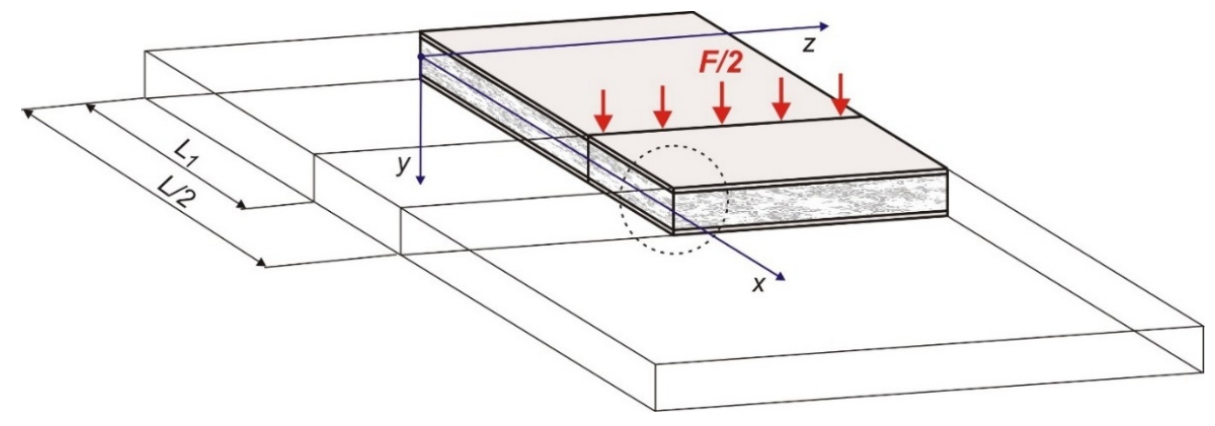

Rys. 5. Model warstwowego pasma płytowego zastosowany w obliczeniach MES

Pasmo płytowe umieszczone jest w kartezjańskim układzie współrzędnych $x, y, z$. Płaszczyzna $x z$ jest płaszczyzną środkową oraz obojętną pasma, oś y zwrócona jest w dół (rys. 5).

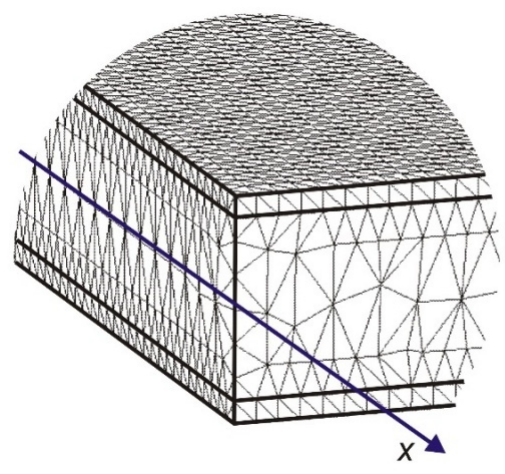

Rys. 6. Fragment siatki MES

(w przybliżeniu ograniczony do obszaru zaznaczonego na rys. 5 kropkowanym okręgiem)

Niżej wyszczególnione warunki brzegowe nałożone na powierzchnie modelu pasma płytowego gwarantują, że zachowa się on jak jedna czwarta całości:

- Model pasma jest swobodnie podparty na krawędzi $x=0$. $Z$ tego powodu przemieszczenia $y$ ściany współpłaszczyznowej z płaszczyzną $y z$ są równe zeru.

- Przemieszczenia $x$ środkowej ściany pasma, równoległej do płaszczyzny $y z$ (dla $x=L / 2$ ), są równe zeru.

- Przemieszczenia $z$ ściany pasma współpłaszczyznowej z płaszczyzną $x y$ (dla $z=0)$ są równe zeru.

Obliczenia wykonano dla tych samych danych, jakie przyjęto w rozwiązaniu analitycznym, otrzymano następujące wartości: $v_{\max }^{(\text {total })}=6.27 \mathrm{~mm}$ i $v\left(L_{1}\right)=5.46 \mathrm{~mm}$. Tak więc maksymalne ugięcie części środkowej $v_{\max }^{(m)}=0.81 \mathrm{~mm}$. 


\section{Badania doświadczalne}

Badania doświadczalne przeprowadzono na próbkach wyprodukowanych i dostarczonych przez firmę Havel Metal Foam GmbH (Niemcy). Taka próbka jest przedstawiona na rys. 7.

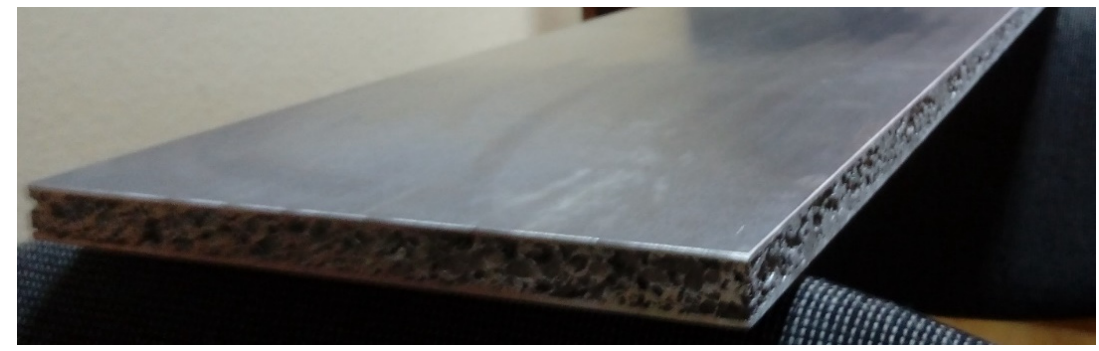

Rys. 7. Trójwarstwowe pasmo płytowe

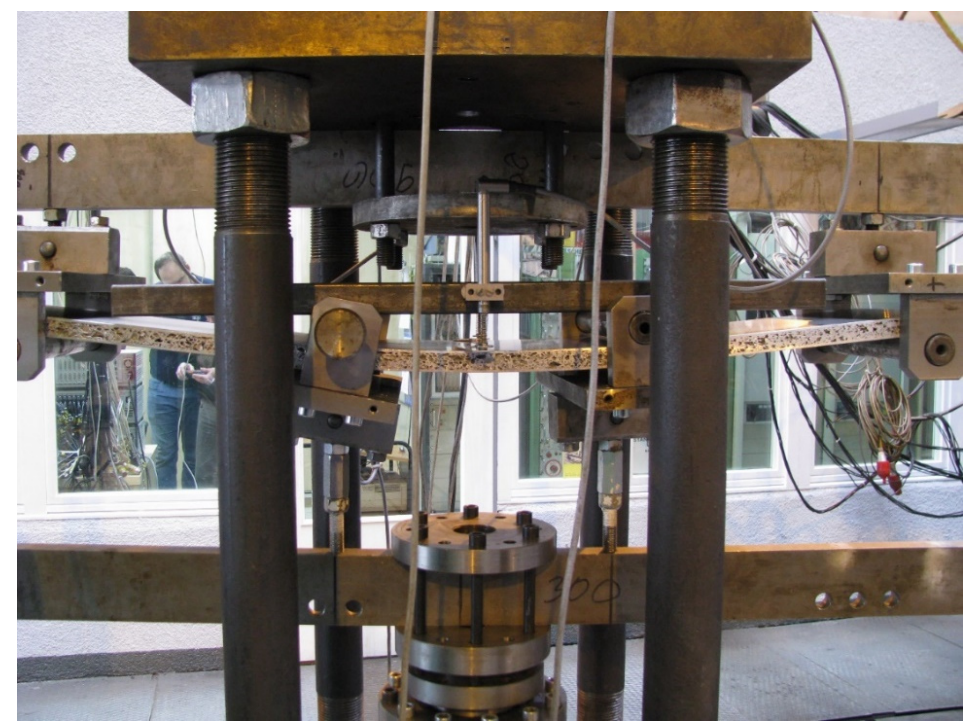

Rys. 8. Ugięte pasmo pod działaniem obciążenia na stanowisku badawczym (Laboratorium - Sieć Badawcza Łukasiewicz - IPS TABOR)

Pasmo zostało zamontowane na stanowisku badawczym i obciążone siłą $F_{0}=2 F$, jak pokazano na rys. 1. Całkowita długość pasma-próbki wynosi $1000 \mathrm{~mm}$. Została ona podparta na rolkach odległych o $L=900 \mathrm{~mm}$. Obciazżenie przyłożono za pomocą dwóch kolejnych rolek rozstawionych na $300 \mathrm{~mm}$, symetrycznie względem próbki. W rezultacie część próbki znajdująca się pomiędzy dwiema rolkami obciążającymi podlega czystemu zginaniu (rys. 8).

Rys. 9. Zależność między obciążeniem $F_{0}$ i maksymalnym ugięciem $v_{\max }^{(m)}$ środka próbki

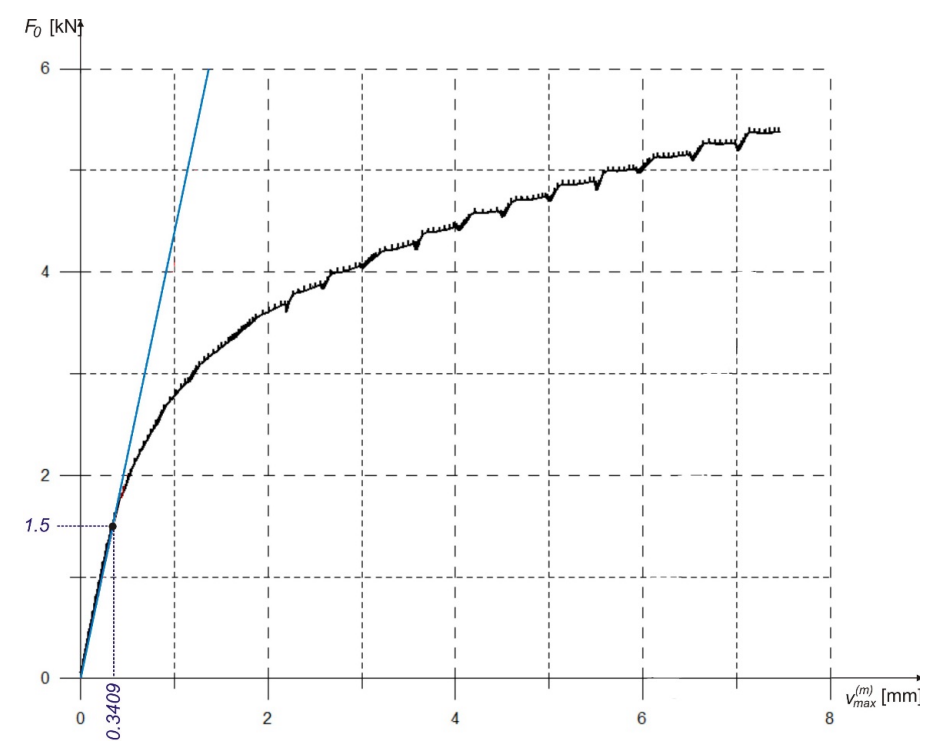


Ta próba umożliwiła wyznaczenie zależności między obciążeniem $F_{0}$ i maksymalnym ugięciem $v_{\max }^{(m)}$ środkowego punktu próbki (przedstawionej na rys. 9).

Można zauważyć, że zginanie sprężyste (proporcjonalne) odbywa się w ograniczonym zakresie obciążenia dla $F_{0}$ ? $1.5 \mathrm{kN}$. Taka siła wywołuje maksymalne ugięcie środkowego punktu próbki wynoszące $v_{\max }^{(m)}=0.3409 \mathrm{~mm}$. Dalszy wzrost obciążenia skutkuje wyraźnym odchyleniem od proporcjonalności. Nieregularności przebiegu krzywej sugerują, że materiał ulega stopniowej destrukcji.

W badaniach analitycznych i numerycznych MES przyjęto wartość obciążenia całkowitego $F_{0}=3000 \mathrm{kN}$, natomiast $\mathrm{w}$ badaniach stanowiskowych stwierdzono, że zginanie pasma-próbki $\mathrm{w}$ zakresie sprężystym jest dla wartości obciążenia $F_{0}$ ? $1.5 \mathrm{kN}$. Maksymalne ugięcia części środkowej próbki wyznaczone analitycznie i numerycznie MES dla tego obciążenia są zatem następujące $v_{\max }^{(m-A n)}=0.41 \mathrm{~mm}$ oraz $v_{\max }^{(m-\mathrm{FEM})}=0.41 \mathrm{~mm}$. Wartości te są o $20 \%$ większe od wyznaczonych doświadczalnie. Należy zauważyć, że ugięcie części środkowej próbki jest różnica ugięcia całkowitego i ugięcia w miejscu działania siły-obciążenia (rys.4), zatem jego wartość jest mała w porównaniu $\mathrm{z}$ wartością ugięcia $\mathrm{w}$ miejscu działania siły-obciążenia $(\sim 15 \%)$.

Firma Havel Metal Foam GmbH stosuje technologię wytwarzania struktur trójwarstwowych z rdzeniem z piany aluminiowej do produkcji wielu różnych elementów konstrukcyjnych. Wyżej analizowane płyty warstwowe można by zastosować jako części podłogi lub poszycia pojazdu szynowego. Kilka przykładowych zastosowań tych struktur produkowanych przez firmę Havel Metal Foam GmbH przedstawiono na rys. $10 \div 12$.

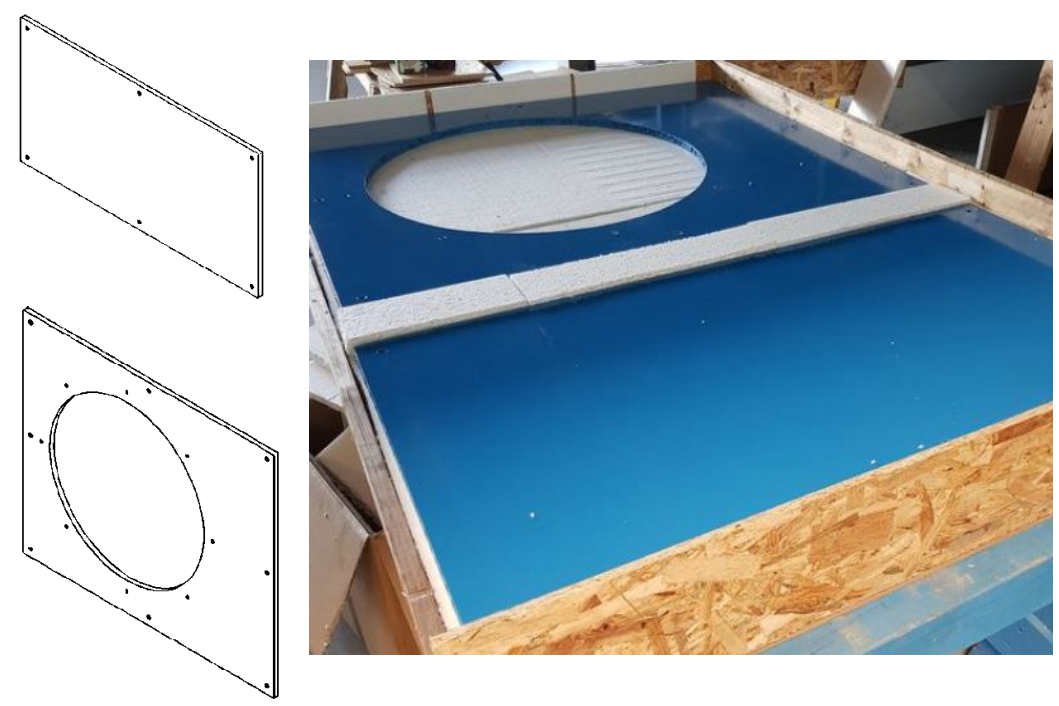

Cover sheet (top): $1.5 \mathrm{~mm} \quad$ Okładzina górna: $1.5 \mathrm{~mm}$

Metal foam core: $17 \mathrm{~mm} \quad$ Rdzeń z piany metalowej: $17 \mathrm{~mm}$

Cover sheet (bottom): $1.5 \mathrm{~mm}$

Okładzina dolna: $1.5 \mathrm{~mm}$

Rys. 10. Pokrywa obudowy sprężarki

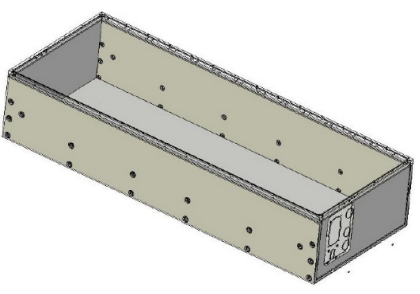

Welded construction $1515 \times 600 \times 298 \mathrm{~mm}$ with integrated $\varnothing 8$ cooling tube system

Konstrukcja spawana $1515 \times 600 \times 298 \mathrm{~mm}$ ze zintegrowanym układem rur chłodzacych $\varnothing 8$

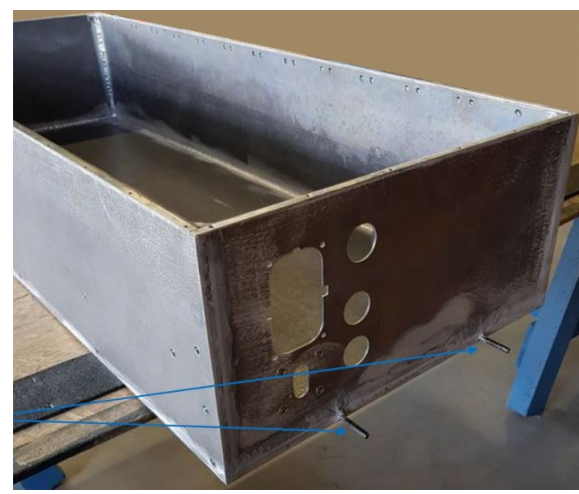

Rys. 11. Skrzynia do systemu akumulatorowego $600 \mathrm{~V}$ przeznaczona do pojazdów z napędem elektrycznym 

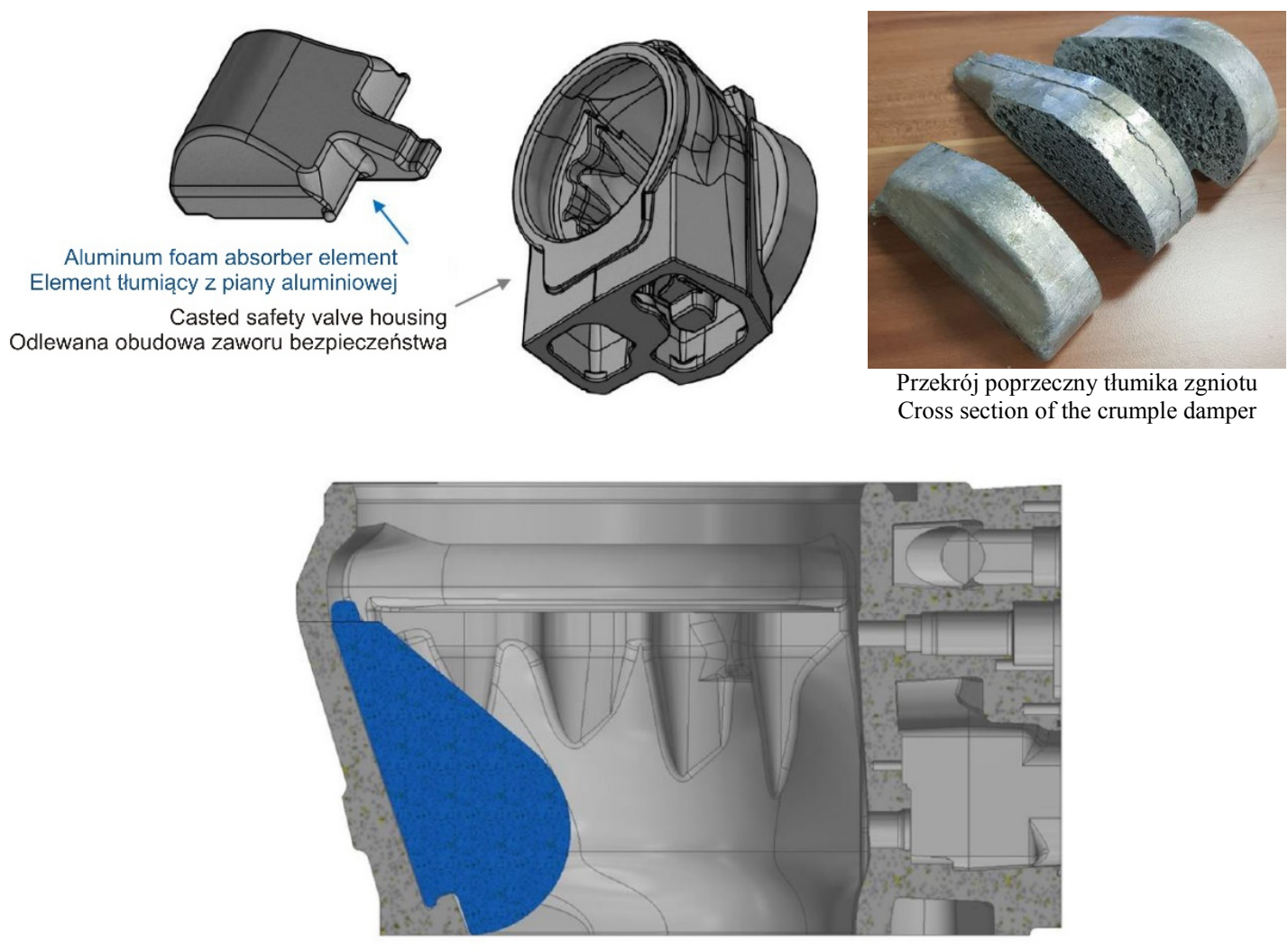

The absorber element inside the casted safety valve housing Element tłumiący wewnątrz obudowy zaworu bezpieczeństwa

Rys. 12. Tłumik zgniotu 5-calowego zaworu bezpieczeństwa

Można założyć, że zastosowanie struktur trójwarstwowych z rdzeniem z pianki aluminiowej będzie się rozszerzało. Struktury takie posiadają wiele zalet, wyróżniają się niewielką masą przy zachowaniu wymaganej wytrzymałości. Mają też korzystne właściwości w przypadku obciążeń udarowych.

\section{Wnioski}

Ugięcia próbki pasma zostały wyznaczone trzema metodami: analitycznie, numerycznie (MES) i doświadczalnie. W celu zrealizowania obliczeń dwiema pierwszymi metodami wartości modułów Younga okładzin i rdzenia przyjęto $E_{f}=72000 \mathrm{MPa}$ (aluminium), $E_{c}=3640 \mathrm{MPa}$, oraz liczbę Poissona rdzenia $v_{c}=0.3$. Porównanie tych dwóch rozwiązań jest zadowalające - wartości ugięcia są zbliżone (Tab.1).

Natomiast podczas próby laboratoryjnej zmierzono tylko maksymalne ugięcie środkowego punktu próbki, a wynik różni się znacznie około $20 \%$ od ugięć wyznaczonych dwiema pierwszymi metodami. Ponadto $\mathrm{w}$ przypadku obciążenia wynoszącego $F_{0}=3000 \mathrm{~N}$ spieniony materiał przechodzi w stan plastyczny, co nie ma miejsca w przypadku obliczeń.

Tablica 1. Porównanie wartości ugięć wyznaczonych analitycznie, numerycznie (MES) i doświadczalnie dla $F_{0}=1500$ kN $(F=750 \mathrm{kN})$

\begin{tabular}{|c|c|c|c|}
\hline $\begin{array}{c}\text { Method } \\
\text { Metoda }\end{array}$ & $\begin{array}{c}\text { Analytical } \\
\text { Analityczna }\end{array}$ & $\begin{array}{c}\text { FEM-numerical } \\
\text { Numeryczna (MES) }\end{array}$ & $\begin{array}{c}\text { Experimental } \\
\text { Doświadczalna }\end{array}$ \\
\hline$F_{0}[\mathrm{kN}]$ & 1.5 & 1.5 & 1.5 \\
\hline$v_{\max }^{(\text {total }}[\mathrm{mm}]$ & 3.185 & 3.14 & - \\
\hline$v\left(L_{1}\right)[\mathrm{mm}]$ & 2.775 & 2.73 & 0.341 \\
\hline$v_{\max }^{(m)}[\mathrm{mm}]$ & 0.41 & 0.41 & - \\
\hline
\end{tabular}

Ugięcie części środkowej próbki, jako różnica ugięcia całkowitego i ugięcia w miejscu działania siły-obciążenia (rys.4), jest mała - wynosi około $15 \%$ w porównaniu z ugięciem w miejscu działania siły-obciążenia.

\section{Bibliografia jak w wersji angielskiej artykułu}

